\title{
Improved Internal Reference Oxygen Sensors with Composite Ceramic Electrodes
}

\author{
Hu, Qiang; Jacobsen, Torben; Hansen, Karin Vels; Mogensen, Mogens Bjerg
}

Published in:

Journal of The Electrochemical Society

Link to article, DOI:

10.1149/2.021210jes

Publication date:

2012

Document Version

Publisher's PDF, also known as Version of record

Link back to DTU Orbit

Citation (APA):

Hu, Q., Jacobsen, T., Hansen, K. V., \& Mogensen, M. B. (2012). Improved Internal Reference Oxygen Sensors with Composite Ceramic Electrodes. Journal of The Electrochemical Society, 159(10), B811-B817.

https://doi.org/10.1149/2.021210jes

\section{General rights}

Copyright and moral rights for the publications made accessible in the public portal are retained by the authors and/or other copyright owners and it is a condition of accessing publications that users recognise and abide by the legal requirements associated with these rights.

- Users may download and print one copy of any publication from the public portal for the purpose of private study or research.

- You may not further distribute the material or use it for any profit-making activity or commercial gain

- You may freely distribute the URL identifying the publication in the public portal

If you believe that this document breaches copyright please contact us providing details, and we will remove access to the work immediately and investigate your claim. 


\section{Improved Internal Reference Oxygen Sensors with Composite Ceramic Electrodes}

Qiang Hu, Torben Jacobsen, Karin Vels Hansen and Mogens Mogensen

J. Electrochem. Soc. 2012, Volume 159, Issue 10, Pages B811-B817. doi: 10.1149/2.021210jes

$\begin{array}{cl}\text { Email alerting } & \begin{array}{l}\text { Receive free email alerts when new articles cite this article - sign up } \\ \text { in the box at the top right corner of the article or click here }\end{array}\end{array}$

To subscribe to Journal of The Electrochemical Society go to:

http:Iljes.ecsdl.org/subscriptions

(C) 2012 The Electrochemical Society 


\title{
Improved Internal Reference Oxygen Sensors with Composite
Ceramic Electrodes
}

\author{
Qiang Hu, ${ }^{\mathrm{Z}}$ Torben Jacobsen, ${ }^{*}$ Karin Vels Hansen, and Mogens Mogensen* \\ Department of Energy Conversion and Storage, Technical University of Denmark, DK-4000 Roskilde, Denmark
}

\begin{abstract}
Potentiometric oxygen sensors with an internal reference electrode, which uses the equilibrium $\mathrm{pO}_{2}$ of the binary mixture of $\mathrm{Ni} / \mathrm{NiO}$ as the reference, are demonstrated. The cells employ Pt or composite ceramics as the sensing electrode. The cells are fabricated by a flexible and potentially low cost method and show high accuracy. The errors in cell voltage are less than $4 \mathrm{mV}$ above $359^{\circ} \mathrm{C}$. The cells exhibit good stability ( $>5100 \mathrm{hrs}$ ), extended working temperature range, good tolerance to thermal and $\mathrm{pO}_{2}$ cycling, fast response and easy recoverability when $\mathrm{Ni}$ is depleted. Both cell fabrication and performance are highly reproducible. The composite ceramics, based on strontium doped manganite and yttria doped zirconia, are proven superior over Pt to serve as the electrode material. (C) 2012 The Electrochemical Society. [DOI: 10.1149/2.021210jes] All rights reserved.
\end{abstract}

Manuscript submitted May 10, 2012; revised manuscript received July 2, 2012. Published August 29, 2012.

Oxygen sensors are widely used in industries for combustion control and monitoring the $\mathrm{pO}_{2}$ of gaseous environments. Potentiometric oxygen sensors obey the Nernst equation:

$$
V_{\text {cell }}=\frac{R T}{4 F} \ln \frac{p_{S}}{p_{R}}
$$

where $V_{\text {cell }}$ is the cell voltage, $R$ is the gas constant, $T$ is the temperature in Kelvin, $\mathrm{F}$ is Faraday's number, $\mathrm{p}_{\mathrm{S}}$ is the $\mathrm{pO}_{2}$ at the sensing electrode and $\mathrm{p}_{\mathrm{R}}$ is the $\mathrm{pO}_{2}$ at the reference electrode. This kind of sensor plays an important role in enhancing combustion efficiency, lowering pollution emission and improving domestic living conditions. ${ }^{1,2}$

Potentiometric oxygen sensors employ an oxide ion conductor, e.g. stabilized $\mathrm{ZrO}_{2}, \mathrm{CeO}_{2}, \mathrm{ThO}_{2}$, as the solid electrolyte to separate sample gas from reference gas. Yttria stabilized zirconia (YSZ) is the most commonly used solid electrolyte at present. The cell voltage of a potentiometric oxygen sensor is developed by virtue of the $\mathrm{pO}_{2}$ difference (strictly speaking, the oxygen fugacity difference) between the two electrodes. The reference $\mathrm{pO}_{2}$ has been air or pure oxygen at a known pressure or on occasion an equilibrium mixture of reactive gases (e.g. $\mathrm{H}_{2} / \mathrm{H}_{2} \mathrm{O}$ or $\mathrm{CO} / \mathrm{CO}_{2}$ ) for which oxygen partial pressures can be calculated. ${ }^{3,4}$ However, delivering the reference gas to the sensor makes the cell structure complex and can become a difficult or impossible task in large industrial equipment applications. ${ }^{4-6}$

There have been efforts to develop potentiometric oxygen sensors with an internal reference. ${ }^{4-14}$ With an internal reference, the cell structure becomes much more compact, which is important to improve mechanical robustness, application adaptability and performance stability of the cell. Haaland, ${ }^{4}$ Hetrick et al., ${ }^{9}$ Maskell et al. ${ }^{15}$ and Kaneko et al. ${ }^{16}$ fabricated pump-gauge devices that consisted of a pump for transmitting oxygen into a small sealed or semi-sealed volume, and a potentiometric gauge for determining the ratio of the $\mathrm{pO}_{2}$ in the sample gas and in the enclosed volume.

A simple way of providing an internal reference $\mathrm{pO}_{2}$ is by using the equilibrium $\mathrm{pO}_{2}$ of a co-existing mixture of a metal and its oxide. As given by the Gibbs phase rule, a thermodynamically equilibrated mixture of a metal and its stoichiometric oxide fixes a $\mathrm{pO}_{2}$ at a given temperature. In this article the internal reference oxygen sensor (IROS) denotes this kind of oxygen sensor. The equilibrium $\mathrm{pO}_{2}$ of the binary mixture is usually very small, i.e., the equilibrium $\mathrm{pO}_{2}$ is $5.5 \times 10^{-17}$ bar at $700^{\circ} \mathrm{C}$ for the binary mixture of $\mathrm{Ni} / \mathrm{NiO}$. Such kinds of binary mixture systems have been reviewed by Maskell et al. . $^{3,17}$ and several attempts have been carried out to develop IROS. Monreal et al. ${ }^{6}$ developed tubular oxygen sensors which used a $\mathrm{Pd} / \mathrm{PdO}$ binary mixture to generate an internal reference $\mathrm{pO}_{2}, \mathrm{Pt}$ or $\mathrm{Ag}$ as the sensing electrodes, and a vitrified enamel cap as the seal. Their cells, with the lower detection limit reaching $10^{-39}$ bar, were able to work with a high accuracy and the tested temperature range was from $450^{\circ} \mathrm{C}$

*Electrochemical Society Active Member.

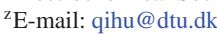

to $650^{\circ} \mathrm{C}$. Mortimer et al..$^{5}$ made tubular IROSes, starting from the binary powder mixtures of $\mathrm{Ni} / \mathrm{NiO}$ or $\mathrm{Pd} / \mathrm{PdO}$. The authors found that the sealing system should be further improved to extend the working life. Chowdhury et al. ${ }^{11}$ made a tubular IROS starting from the mixture of $\mathrm{Ni} / \mathrm{NiO}$ with a ratio of $9: 1$. The much larger proportion of $\mathrm{Ni}$ was assumed to make enough $\mathrm{Ni}$ powder survive the following high temperature treatments such as electrode sintering and cell sealing. For instance, sealing of the sensor was realized at $1400^{\circ} \mathrm{C}$. van Setten et al. ${ }^{12}$ made planar IROSes using $\mathrm{Ni} / \mathrm{NiO}$ as the binary mixture. The electrode fabrication and sealing were realized by pulsed laser deposition (PLD). The binary mixture of $\mathrm{Ni} / \mathrm{NiO}$ was in situ formed by a coulometric titration technique and the starting material was $\mathrm{NiO}$ rather than the mixture of $\mathrm{Ni} / \mathrm{NiO}$. Spirig et al. ${ }^{14}$ used a special grain boundary sliding technique, which needs pressured high temperature treatments $\left(>1200^{\circ} \mathrm{C}\right)$ for bonding sensor components, to develop several cells with three kinds of binary mixtures $(\mathrm{Ni} / \mathrm{NiO}, \mathrm{Pd} / \mathrm{PdO}$ and $\mathrm{Ru} / \mathrm{RuO}_{2}$ ). Kaneko et al. ${ }^{18}$ developed $\mathrm{Pd} / \mathrm{PdO}$ based cells with the binary mixture embedded into a ceramic superstructure. Apart from the above solid state IROSes, liquid internal reference oxygen sensors were also developed by Kaneko et al. ${ }^{13}$ and Zhuiykov. ${ }^{19}$ The reported stability of IROSes is rarely longer than $100 \mathrm{hrs}$ and leaks are commonly believed an important factor accounting for the short lifetime. The possible leak sources were discussed by Kaneko et al. ${ }^{16}$ The stability was mentioned to be in an order of months for the cells developed by Spirig et al., ${ }^{14}$ however, due to the drift problem the cells needed to be operated in a 'pump-out' mode, which is an operation to remove the oxygen from the reference electrode, in order to measure the cell voltage responding to the $\mathrm{pO}_{2}$ changes in the sample gas. Thus, IROSes have never been successfully commercialized to an appreciable extent due to reasons such as poor reproducibility, unreliable measurements, costly fabrication and frequent maintenance.

Noble metals such as Pt are the dominant material for electrodes due to historical reasons. It is well known that electrode microstructure is important for the sensor performance in terms of stability, response speed and reliability etc. ${ }^{2,30-22}$ and must be carefully designed, realized and maintained to achieve a good performance. However, under the practical harsh working conditions (high temperature, dusty and "poisonous" compounds), the microstructure of metal electrodes can hardly be maintained in the long term. On the other hand, since ceramic is generally refractory in nature and characteristic of high resistance to severe working conditions, there have been efforts to develop ceramic electrodes for gas sensors. Some perovskites, fluorites and their doped families are known to possess a large range of electronic, ionic and catalytic properties, ${ }^{23-27}$ which are important for developing the electrode material of gas sensors. Studies have confirmed the superiority in morphology maintenance of $\mathrm{LaMnO}_{3}$, $\mathrm{La}(\mathrm{Sr}) \mathrm{CoO}_{3}$ and the much better sulfur resistance of terbia doped YSZ in high sulfur (10-20\% $\mathrm{SO}_{2}$ ) environment over Pt, respectively. ${ }^{20,28-30}$ The composite ceramics consisting of $\mathrm{La}_{1-x} \mathrm{Sr}_{x} \mathrm{MnO}_{3 \pm \delta}$ and $8 \mathrm{~mol} \%$ yttria stabilized zirconia have a good electrochemical performance and are widely used for the oxygen electrode of solid oxide fuel cells 


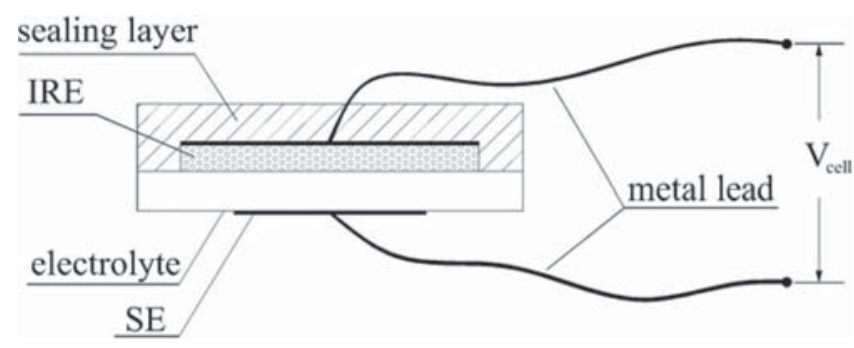

Figure 1. Schematic illustration of an IROS. It consists of an IRE, an electrolyte, an SE and a sealing layer. $\mathrm{V}_{\text {cell }}$ is the voltage between the IRE and the $\mathrm{SE}$, which is used for $\mathrm{pO}_{2}$ measurement.

$(\mathrm{SOFCs})^{31-33}$ and solid oxide electrolysis cells (SOECs). ${ }^{34,35}$ The properties of the composite ceramics are intensively studied with focuses on stability, reproducibility, and electrochemical activity. In addition, a ceramic electrode is also advantageous in electrode microstructure design and cell cost reduction. The cost of ceramic materials is much lower than that of precious metals such as Pt, and ceramic electrode microstructures can be designed to optimize the electrochemical properties of the electrodes. ${ }^{36-40}$

\section{Experimental}

Fabrication.- The schematic structure of an IROS is shown in Figure 1. The cell comprises an internal reference electrode (IRE), an electrolyte, a sensing electrode (SE) and a sealing layer.

The IRE was made from $\mathrm{NiO}$ (Alfa Aesar) and $8 \mathrm{~mol} \%$ yttria stabilized zirconia (8YSZ) from Tosoh. Both powders contained a calcined part and an uncalcined part. Calcination of $8 \mathrm{YSZ}$ was performed at $1100^{\circ} \mathrm{C}$ for $2 \mathrm{hrs}$ and calcination of $\mathrm{NiO}$ was performed at $800^{\circ} \mathrm{C}$ for 3 hrs. NiO, calcined NiO, 8YSZ and calcined 8YSZ powders, with a weight ratio of $3: 3: 2: 2$, were ball-mill mixed and made into an ink with a terpineol based solvent. The ink was screen-printed on $10 \times 10 \mathrm{~mm}^{2}$ tapes of $10 \mathrm{~mol} \% \mathrm{Sc}_{2} \mathrm{O}_{3}$ and $1 \mathrm{~mol} \% \mathrm{Y}_{2} \mathrm{O}_{3}$ stabilized zirconia (ScYSZ) from Daiichi or $8 \mathrm{YSZ}$. The tapes were made in-house. The screen printed IRE was sintered at $1350^{\circ} \mathrm{C}$ in air for $2 \mathrm{hrs}$ and the mass of the IRE was found from the weight gain after the IRE preparation.

Fabrication of the composite sensing electrode (CSE) started from an ink containing equal amounts of $\left(\mathrm{La}_{0.75} \mathrm{Sr}_{0.25}\right)_{0.95} \mathrm{MnO}_{3 \pm \delta}$ (LSM25) and 8YSZ. Graphite (Aldrich), used as pore former, was added into the ink with a weight ratio of $20 \%$. The ink was screen printed onto the electrolyte side opposite to the IRE and sintered at $1050^{\circ} \mathrm{C}$ for $2 \mathrm{hrs}$. $\mathrm{Pt}$ was also used as the SE in some cells to compare cell performance. The Pt electrode was prepared by brushing Pt paste (FERRO) on the side opposite to the IRE, and then heated at $1050^{\circ} \mathrm{C}$ for $2 \mathrm{hrs}$. The average electrode area was $0.25 \mathrm{~cm}^{2}$.

Some IRE and/or SE were impregnated with $10 \mathrm{~mol} \% \mathrm{Sm}_{2} \mathrm{O}_{3}$ doped $\mathrm{CeO}_{2}, \mathrm{Ce}_{0.8} \mathrm{Sm}_{0.2} \mathrm{O}_{1.9}$ (SDC20). The impregnation was performed by dripping a nitrate solution on the electrode (IRE and/or SE) surface and then decomposing the nitrate at $700^{\circ} \mathrm{C}$ for $2 \mathrm{hrs}$. The nitrate solution, $\mathrm{Ce}_{0.8} \mathrm{Sm}_{0.2}\left(\mathrm{NO}_{3}\right)_{\mathrm{x}}$, consisting of $1 \mathrm{M}, 20 \mathrm{~mol} \% \mathrm{Sm}\left(\mathrm{NO}_{3}\right)_{3}$ and $80 \mathrm{~mol} \% \mathrm{Ce}\left(\mathrm{NO}_{3}\right)_{3}$, was prepared from $\mathrm{Sm}\left(\mathrm{NO}_{3}\right)_{3} \cdot 6 \mathrm{H}_{2} \mathrm{O}$ (Alfa Aesar) and $\mathrm{Ce}\left(\mathrm{NO}_{3}\right)_{3} \cdot 6 \mathrm{H}_{2} \mathrm{O}$ (Alfa Aesar). Four times impregnation of SDC20 resulted in a load of ca. $6 \mathrm{mg} \cdot \mathrm{cm}^{-2}$ for the IRE and ca. $3 \mathrm{mg} \cdot \mathrm{cm}^{-2}$ for the SE.

Some IRE had a gold coating that was applied by magnetron sputtering in argon under a pressure of $50 \mathrm{mTorr}$. The discharge voltage and current were $390 \mathrm{~V}$ and $400 \mathrm{~mA}$, respectively, and the sputtering time was 1 hour. A Pt lead used for connection between the IRE and external circuits was adhered to the IRE by Pt paste, followed by a heat-treatment at $700^{\circ} \mathrm{C}$ for 1 hour. After electrode preparation, SDC20 impregnation and Pt lead connection, the glass sealing was applied. A silica based glass powder, developed in-house, was mixed with a polyethylenglycol-containing solution and the resulting slurry was used to cover the IRE. The glass sintering was carried out at $960^{\circ} \mathrm{C}$ for $2 \mathrm{hrs}$ and the cooling rate from $960^{\circ} \mathrm{C}$ was $2^{\circ} \mathrm{C}$ per minute.
Cell test.-Cells were placed in an alumina experimental setup for accuracy test. The setup has an inner diameter of $69 \mathrm{~mm}$ and a length of $495 \mathrm{~mm}$, and room for four cells to be tested in one batch. For the long term stability test, the cell was placed in a smaller quartz tube with an inner diameter of $25 \mathrm{~mm}$ and a length of $290 \mathrm{~mm}$. Due to a slight leak it was not possible to establish a very low $\mathrm{pO}_{2}$ inside the quartz setup. The alumina and the quartz setups can maintain a $\mathrm{pO}_{2}$ as low as $1 \times 10^{-4}$ and $2 \times 10^{-2}$ bar, respectively. The response time tests were carried out in the smaller quartz setup. The atmosphere in all tests was controlled by mass flow controllers (SLA5850, Brooks) and the source gas species included compressed air, oxygen (N35, Air Liquid) and nitrogen (N48, Air Liquid). The minimum and maximum flow rates of the mass flow controllers were 0.1 and 6 slph (standard liters per hour), respectively.

Before an IROS becomes functional, its IRE needs to be electrochemically reduced to form the binary mixture of $\mathrm{Ni} / \mathrm{NiO}$. Potential sweeps were performed on the cells with an unreduced IRE in order to find an appropriate potential to reduce $\mathrm{NiO}$. The IRE reduction and potential sweep were carried out at $664^{\circ} \mathrm{C}$ and in air. If nothing else is mentioned below, the IRE of a cell based on Pt sensing electrode was reduced at $-1.1 \mathrm{~V}$ vs. SE $\left(\mathrm{p}_{\mathrm{S}}=0.21 \mathrm{~atm}\right)$ and the IRE of a cell based on ceramic sensing electrodes was reduced at $-0.9 \mathrm{~V}$ vs. SE $\left(\mathrm{p}_{\mathrm{s}}=\right.$ $0.21 \mathrm{~atm})$. The reduction time was 65 minutes. Chronoamperometry was carried out during reduction and from the curve of current vs. time the amount of reduced $\mathrm{NiO}$ can be determined.

The microstructure and chemical composition of the cells were investigated in a Zeiss Supra 35 field emission gun scanning electron microscope, equipped with a Noran System Six Model 3000 energy dispersive X-ray spectrometer, after sample polishing. The potential sweeps, electrochemical impedance spectroscopy (EIS) and chronoamperometry were performed by a Solartron 1250 frequency response analyser along with a Solartron SI 1287 electrochemical interface. The electrochemical measurement software was Elchemea 5.1.3 that was developed in-house. The electrochemical impedance spectroscopy was performed with a bias voltage equal to the voltage of the cell being tested. By this means, the obtained impedance spectra were reproducible and the impedance spectroscopy would not damage the cell being tested. In the accuracy tests, cell voltages were read by a Keithley 2700 multimeter and the stabilization period for a new test condition, i.e., $\mathrm{pO}_{2}$ or temperature, was at least $2 \mathrm{hrs}$. The accuracy of Keithley 2700 in the voltage range of $1 \mathrm{~V}$ is $\pm(25 \mathrm{ppm}$ of reading $+7 \mathrm{ppm}$ of range). In the response time tests the flow rate of nitrogen was kept at $4 \mathrm{slph}$ while the flow rate of oxygen varied between 0.1 and 1 slph. A Keithley KUSB-3108, with a much higher recording frequency $(\geq 1 \mathrm{~Hz})$ and an accuracy of $0.01 \%$ at a gain of 1 , was employed to record the cell voltage change in the course of $\mathrm{pO}_{2}$ change. All the involved thermodynamic calculations such as the theoretical cell voltage were carried out by FactSage 5.5. ${ }^{41}$

\section{Results}

Appearance and structure of IROSes.- Figure 2a shows the size and appearance of two IROSes and (b) shows a SEM image of the polished cross section of a tested cell, respectively. The structure of the cell of (b) was IRE/ScYSZ/CSE. Since Pt paste and sealing layer

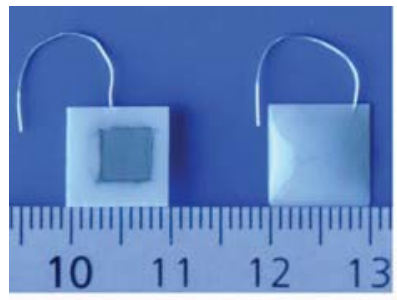

(a)

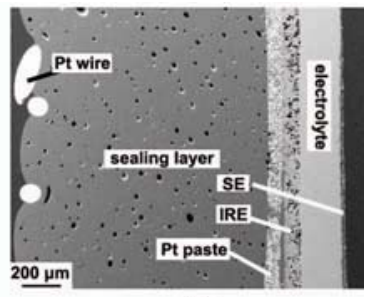

(b)
Figure 2. (a) Photo of two IROSes, both with foot print ca. $10 \times 10 \mathrm{~mm}$. (b) SEM image (Inlens) of the cross section of a polished cell. 


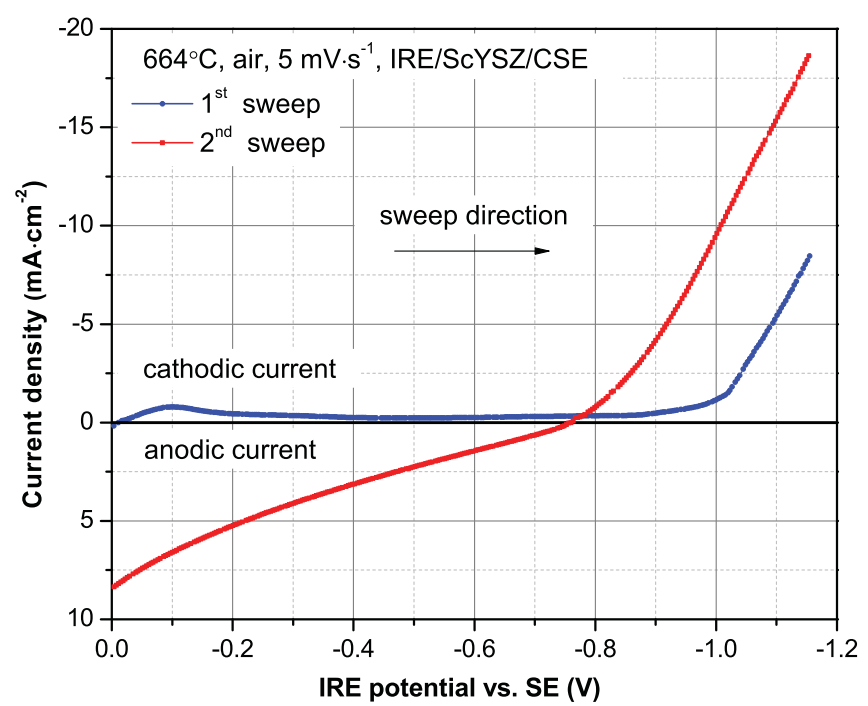

Figure 3. Potential sweeps on an IROS with structure IRE/ScYSZ/CSE. The sweeps were cyclically performed between 0 and $-2.0 \mathrm{~V}$, but only the sections between 0 to $-1.15 \mathrm{~V}$ of the first and the second sweeps are presented for clarity.

were used in all cells, they are left out in the cell structure notation for simplicity. As shown by (b), the contact between the Pt paste and the IRE was in this case not uniform and a portion of Pt paste had no access to the IRE. The bubbles in the sealing layer did not connect to each other, meaning that the sealing was hermetic.

Electrochemical reduction of NiO.- Potential sweeps were performed on cells with an unreduced IRE in order to find an appropriate cell voltage to reduce $\mathrm{NiO}$. Figure 3 presents results on a cell with structure IRE/ScYSZ/CSE. The potential sweeps, with a rate of $5 \mathrm{mV} \cdot \mathrm{s}^{-1}$, were cyclically performed between 0 and $-2.0 \mathrm{~V}$ for four times, but only the sections between 0 to $-1.15 \mathrm{~V}$ of the first and the second sweeps are presented for clarity, and the events taking place below $-1.15 \mathrm{~V}$ has for this context only the effect of reducing more $\mathrm{NiO}$, i.e., forming more and bigger $\mathrm{Ni}$ metal particles. The sweep curves became almost identical after the first sweep. A small peak occurred at ca. $-100 \mathrm{mV}$ during the first sweep but it did not reappear in the second sweep. After the small peak, the current density started to increase numerically from ca. $-850 \mathrm{mV}$ and the increase became significantly faster from ca. $-1.0 \mathrm{~V}$. After the first sweep, the IRE had an equilibrium potential of $-767 \mathrm{mV}$ vs. air, and an anodic current was obtained when the second sweep was initialized from 0 $\mathrm{V}$. In the second sweep, the current changed from anodic to cathodic at $-760 \mathrm{mV}$ and then showed a significant increase, with a slope approximately equal to that in the first sweep when the potential was below $-1050 \mathrm{mV}$.

Cell voltage measurements. - Figure 4 shows the measured cell voltage, $\mathrm{V}_{\text {cell }}$, of 5 cells with varied cell structures for three $\mathrm{pO}_{2}$ levels, $1.64 \times 10^{-2}, 0.21$ and $1 \mathrm{~atm}$, in a temperature range of $210-664^{\circ} \mathrm{C}$. The theoretical cell voltage, $\mathrm{V}_{\text {theo }}$, is also given. The '(SDC20)' to the right of the electrode in cell structure notations means that the electrode has SDC20 impregnation. Above $450^{\circ} \mathrm{C}$ the voltages of all cells agreed with the theoretical value well. Cell 1 that was based on Pt electrode had a larger voltage error. The voltage errors of cell 1 were $\leq 4 \mathrm{mV}$ and $\leq 17 \mathrm{mV}$ at $469^{\circ}$ and $359^{\circ} \mathrm{C}$ respectively. The voltage errors of other cells based on ceramic electrodes were $\leq 2 \mathrm{mV}$ and $\leq 4 \mathrm{mV}$ at $469^{\circ}$ and $359^{\circ} \mathrm{C}$ respectively. The voltage error increased with decreasing temperature. At a low temperature of $263^{\circ} \mathrm{C}$, cell 5 that had both electrodes impregnated by SDC20 had the lowest voltage error of $\leq 16 \mathrm{mV}$ among the five cells. Figure $4 \mathrm{a}-4 \mathrm{c}$ shows that $\mathrm{V}_{\text {cell }}$ was significantly lower than $\mathrm{V}_{\text {theo }}$ at the temperatures below $260^{\circ} \mathrm{C}$. Therefore

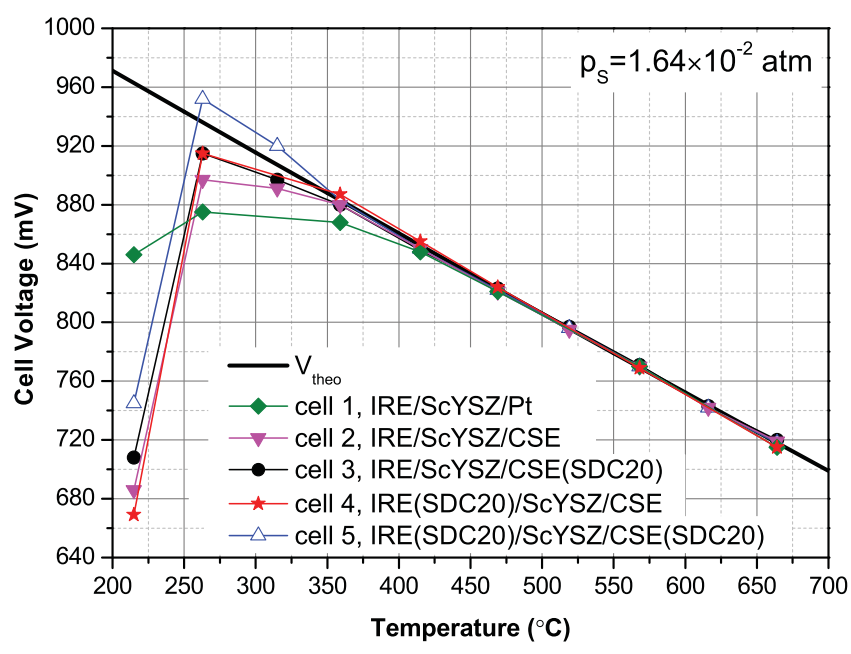

(a)

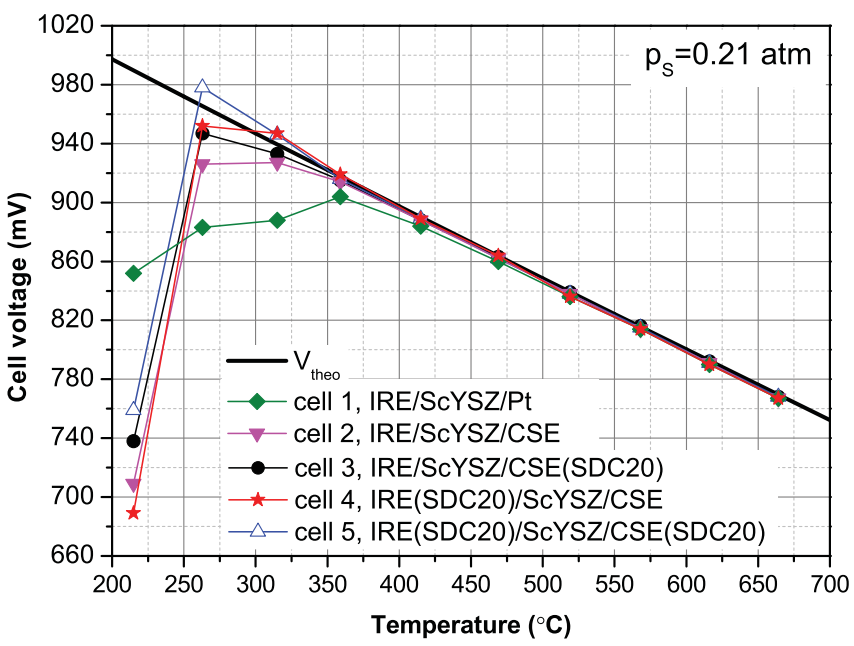

(b)

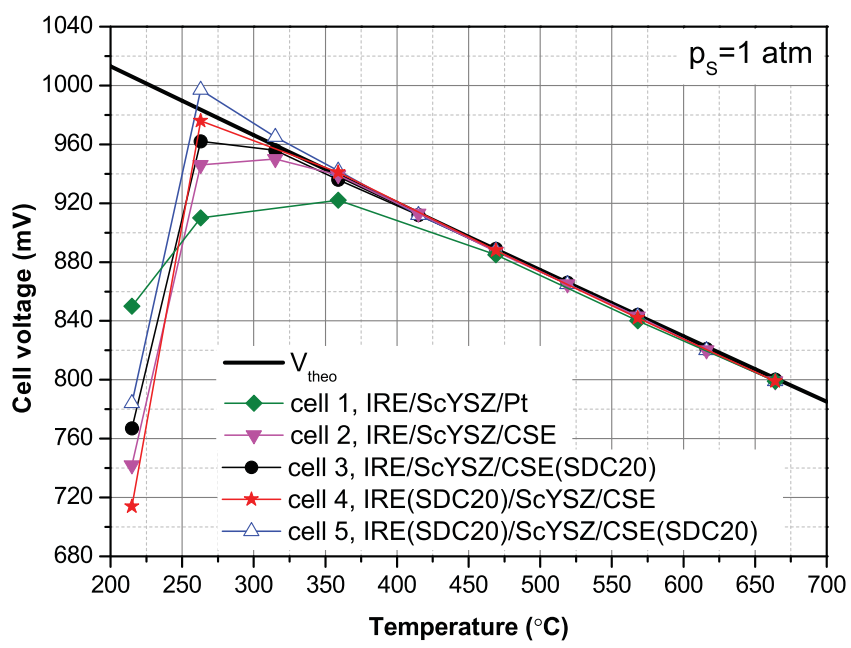

(c)

Figure 4. The measured cell voltage, $\mathrm{V}_{\text {cell }}$, and the theoretical cell voltage, $\mathrm{V}_{\text {theo }}$, at three $\mathrm{pO}_{2}$ levels: (a) $0.0164 \mathrm{~atm}$, (b) $0.21 \mathrm{~atm}$ and (c) $1 \mathrm{~atm}$. The composite ceramics show advantages over $\mathrm{Pt}$ to serve as sensing electrode material in terms of an extended working temperature range and a smaller error. Cell structures are given in the figure legends. 


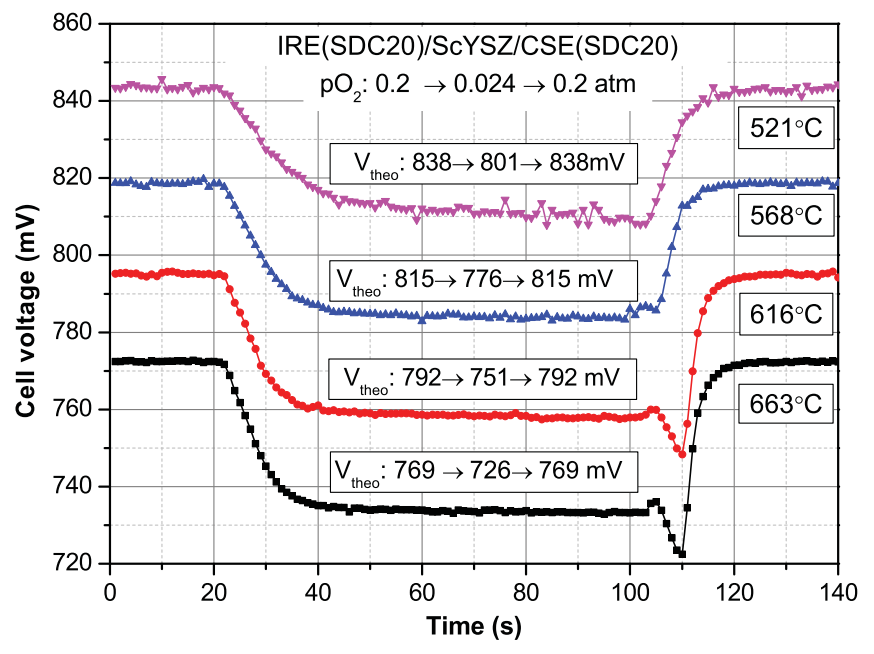

Figure 5. Cell voltage variation in the course of $\mathrm{pO}_{2}$ cycling. Dips in cell voltage seen when $\mathrm{pO}_{2}$ was changed back to 0.2 atm were possibly caused by the PID setting of the mass flow controllers. Response time depends on temperature and direction of $\mathrm{pO}_{2}$ change.

$260^{\circ} \mathrm{C}$ is the suggested lowest reliable operation temperature for the cells presented here unless the cell voltage is calibrated against gases with well-known oxygen partial pressures. The cells with composite ceramic electrodes show advantages over the one with Pt electrode in the aspects of an extended working temperature range and smaller errors.

Response time.- Response time of the cell was examined by changing $\mathrm{pO}_{2}$ while recording the cell voltage. Figure 5 shows cell voltage variations in a $\mathrm{pO}_{2}$ cycling at $521^{\circ} \mathrm{C}, 568^{\circ} \mathrm{C}, 616^{\circ} \mathrm{C}$ and $663^{\circ} \mathrm{C}$, respectively. During the cycling $\mathrm{pO}_{2}$ varied between 0.024 and $0.2 \mathrm{~atm}$. The cell responded to $\mathrm{pO}_{2}$ variations quickly and it is found that: 1) response time depends on the direction of $\mathrm{pO}_{2}$ change. Changing $\mathrm{pO}_{2}$ from high to low takes longer time than the inverse process. For example, upon changing the $\mathrm{pO}_{2}$ from 0.2 to 0.024 atm it took ca. 30 seconds at $663^{\circ} \mathrm{C}$ to reach a stable cell voltage, whereas the cell voltage stabilized within 15 seconds when the $\mathrm{pO}_{2}$ was changed from 0.024 to $0.2 \mathrm{~atm}$; 2) response time depends on temperature. Higher temperature makes the response time shorter. For example, when changing the $\mathrm{pO}_{2}$ from 0.2 to 0.024 atm it took ca. 45 seconds at $521^{\circ} \mathrm{C}$ to reach the stable voltage, whereas it took ca. 30 seconds at $663^{\circ} \mathrm{C}$. The measured cell voltages were a bit higher than the theoretical values, especially under the low $\mathrm{pO}_{2}$ condition. As mentioned above, the small quartz setup used for the response time tests had a small leak, and thus the relative errors at 0.024 atm in this setup were larger than at $0.2 \mathrm{~atm}$. Dips in cell voltage were seen when $\mathrm{pO}_{2}$ was changed back to $0.2 \mathrm{~atm}$. This was possibly caused by the PID setting of the mass flow controllers. The dips were more pronounced at high temperatures, i.e., $663^{\circ} \mathrm{C}$ and $616^{\circ} \mathrm{C}$ since the cell responded faster to a $\mathrm{pO}_{2}$ variation at high temperature.

Stability, recoverability and thermal cycling.- Due to leaks and the very low but finite electronic conductivity of the electrolyte, $\mathrm{Ni}$ particles in the IRE will eventually be oxidized in the long run when the $\mathrm{pO}_{2}$ at the sensing electrode is higher than the equilibrium $\mathrm{pO}_{2}$ of $\mathrm{Ni} / \mathrm{NiO}$. This will cause the cell voltage to approach zero. In order to test the stability of cell voltage, two cells with different initial IRE reduction degree were compared over time as shown in Figure 6. Both cells had the structure of (Au)IRE/8YSZ/Pt and their IREs were reduced at $-1.1 \mathrm{~V}$. The '(Au)' to the left of the 'IRE' in the cell structure notation means that the IRE has an Au coating. One IRE (filled squares) had $67 \%$ of the $\mathrm{NiO}$ reduced while the other (filled circle) had $11 \%$ of the $\mathrm{NiO}$ reduced. The voltage of the former cell did not show any voltage decrease after $90 \mathrm{hrs}$, whereas the voltage of the

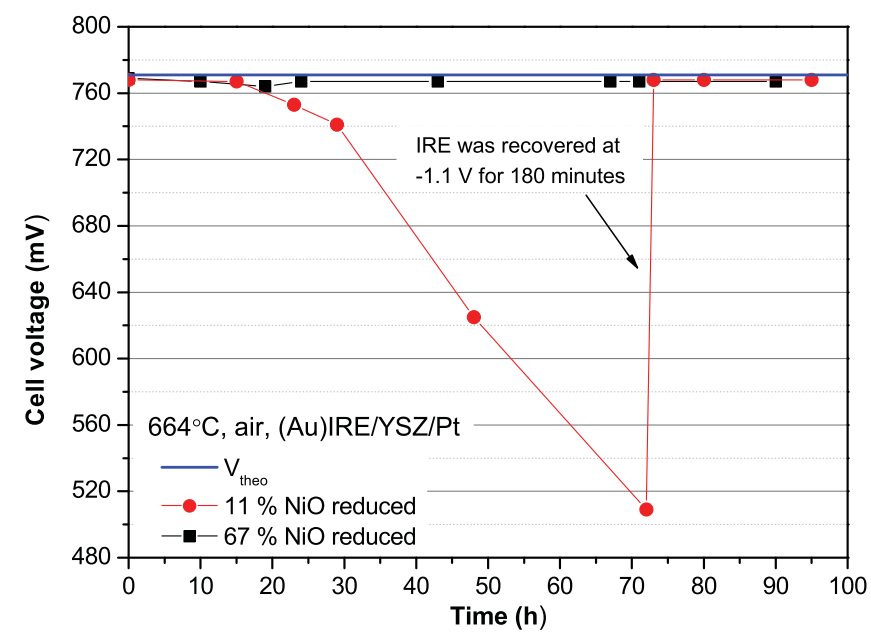

Figure 6. The effect of IRE reduction degree on cell voltage stability. Both cells had a structure of (Au)IRE/8YSZ/Pt and their IREs were reduced at $-1.1 \mathrm{~V}$. The cell working stably had $67 \%$ of $\mathrm{NiO}$ reduced. The cell in which $11 \%$ of $\mathrm{NiO}$ was reduced had a voltage decrease after $15 \mathrm{hrs}$, but the cell voltage was recovered.

latter cell started to decrease after $15 \mathrm{hrs.} \mathrm{With} \mathrm{a} \mathrm{recovery} \mathrm{("recharge")}$ at $-1.1 \mathrm{~V}$ for $3 \mathrm{hrs}$ the voltage of the latter cell was restored. This means that the cell voltage decrease due to Ni depletion is recoverable.

Figure 7 shows the stability test of a cell with structure IRE(SDC20)/ScYSZ/CSE(SDC20). The test included $\mathrm{pO}_{2}$ cycling between 0.024 and 0.2 atm every $12 \mathrm{hrs,} \mathrm{giving} \mathrm{cell} \mathrm{voltages} \mathrm{at} \mathrm{two}$ levels. The IRE of the cell was reduced at $-1.0 \mathrm{~V}$ for 50 minutes, corresponding to a reduction of $43 \%$ of the $\mathrm{NiO}$, and had no any recovery operation during the test. The cell voltage was still stable after $5100 \mathrm{hrs}$. Since the setup had a small leak (see Experimental), the cell voltage at the low $\mathrm{pO}_{2}$ level was slightly higher, ca. $4 \mathrm{mV}$, than the theoretical. Nevertheless, the cell voltages at both $\mathrm{pO}_{2}$ levels were rather stable. Due to disturbances from impedance spectroscopy and slight operation condition variations, such as humidity and temperature fluctuations, minor fluctuations of a few $\mathrm{mV}$ in the cell voltage were seen.

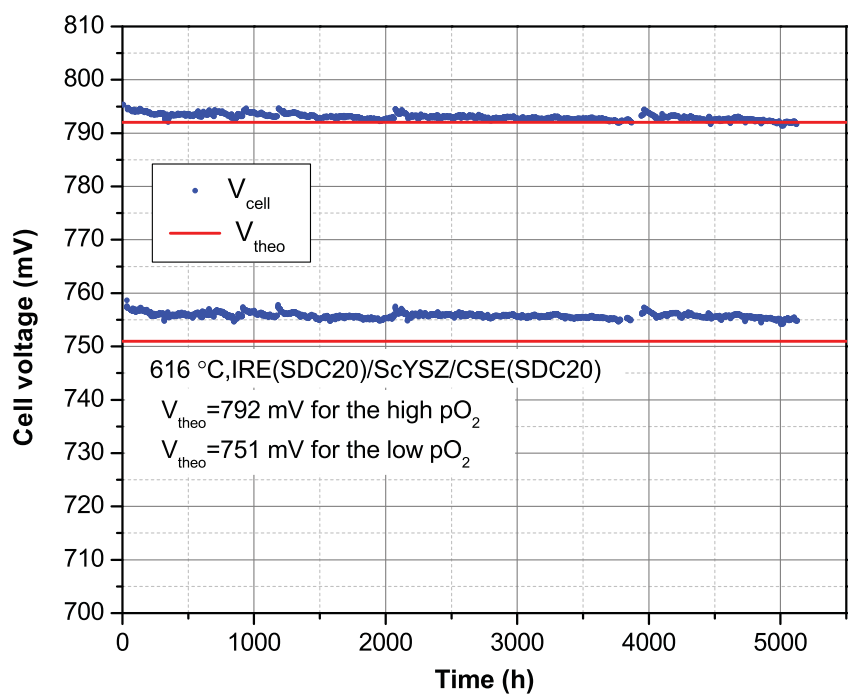

Figure 7. Stability test of an appropriately reduced cell with structure IRE(SDC20)/ScYSZ/CSE(SDC20). The test included $\mathrm{pO}_{2}$ cycling between 0.024 and 0.2 atm every $12 \mathrm{hrs}$. Due to a small leak of the test setup the cell voltage at the low $\mathrm{pO}_{2}$ level is slightly higher, ca. $4 \mathrm{mV}$, than the theoretical, but the cell voltages at both $\mathrm{pO}_{2}$ levels were rather stable after $5100 \mathrm{hrs}$. 


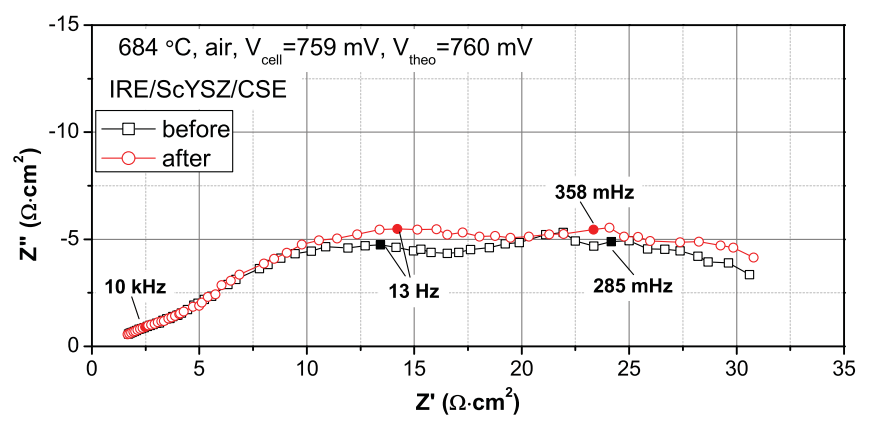

Figure 8. The impedance spectra and cell voltage before and after a thermal cycling between $684^{\circ} \mathrm{C}$ and $25^{\circ} \mathrm{C}$. The cell structure was IRE/ScYSZ/CSE. Electrochemical properties of the cell were well maintained in the thermal cycling.

Tolerance of the cell toward thermal cycling was examined by thermal cycling between $684^{\circ} \mathrm{C}$ and $25^{\circ} \mathrm{C}$. Figure 8 shows the impedance spectra before and after the thermal cycling. The impedance spectrum varied slightly after the thermal cycling, and $\mathrm{V}_{\text {cell }}$ kept unchanged, indicating that the cell electrochemical properties were not significantly affected by the thermal cycling, and the thermal expansion match among cell components had been realized to a large extent.

\section{Discussion}

Considerations in cell fabrication.- The chosen size of $10 \times 10 \mathrm{~mm}$ of the tested cells proved to be a reasonably handy size for the experimental setup. The flexible fabrication method makes it feasible to reduce cell size further in cases where it might be needed. Including advantages such as fabrication cost saving and more adaptable installation, a smaller cell size is also favorable in order to realize a smaller temperature difference within the cell and thus improve accuracy. ${ }^{3}$ Due to the lowered operation temperature, materials with a potentially lower cost, i.e., Ni paste, $\mathrm{Ni} / \mathrm{Cu}$ containing alloys or stainless steel conductor wires instead of Pt paste may be used for electrical connection. This is helpful for further cutting fabrication cost.

In this study the binary mixture of $\mathrm{Ni} / \mathrm{NiO}$ is formed in situ after the electrode sintering and sealing procedures by electrochemical reduction of $\mathrm{NiO}$, a procedure introduced by van Setten et al. ${ }^{12}$ before. By this means the preparation of IRE can start from $\mathrm{NiO}$ instead of the mixture of $\mathrm{Ni}$ and $\mathrm{NiO}$ normally applied,,$^{5,6,11}$ and the inadvertent oxidation of Ni during cell fabrication is avoided. In our cells the IREs are composite and include a network of 8YSZ, meaning that the reduction of $\mathrm{NiO}$ can take place within whole electrode and is no longer confined to a rather narrow section of the IRE/electrolyte interface.

The small peak at ca. $-100 \mathrm{mV}$, occurring in the first sweep of Figure 3, corresponds to the removal of the residual oxygen sealed in the IRE. This process requires a relatively low polarization and the amount of residual oxygen is $1.5 \times 10^{-8} \mathrm{~mol}$, known from the chronoamperometry. After the first sweep, the binary mixture of $\mathrm{Ni} / \mathrm{NiO}$ had been formed, indicated by a stable open circuit voltage. This open circuit voltage, $767 \mathrm{mV}$ is rather close to the theoretical value of $770 \mathrm{mV}$. Since the residual oxygen resulting from the sealing process had been depleted during the first sweep, the peak of oxygen removal did not reappear in the following sweeps. In cases that oxygen was pumped into the IRE during a cyclic potential sweep, it reacted by the already formed $\mathrm{Ni}$ particles into $\mathrm{NiO}$.

In Figure 3 it is seen that the potential from which the current density started to significantly increase had changed from ca. $-1.05 \mathrm{~V}$ in the first sweep to $-0.85 \mathrm{~V}$ in the second sweep. When the sweep potential started from $0 \mathrm{~V}$ in the first sweep, Ni particles had not been formed. Since the formation of Ni nuclei needs an extra polarization, ${ }^{42,43}$ the significant increase in the current density took place at a more negative potential such as below $-1.05 \mathrm{~V}$. However, once the Ni nuclei had been formed, the extra polarization was not required. Therefore in the second sweep the current density started to increase from a more positive potential such as $-0.85 \mathrm{~V}$. The significant increase in the current density corresponds to the reduction of $\mathrm{NiO}$. Due to the same kinetics both sweeps have an almost identical slope when the sweep potential is very negative, i.e., below $-1.05 \mathrm{~V}$.

Stability has been a challenge preventing the commercialization of IROS and is influenced by several factors. For example, thermal expansion compatibility and reactivity among cell components, i.e., electrodes, electrolyte and sealing glass. The material systems such as the sealing glass and electrode materials of the cells show in this study are carefully selected to assure a general compatibility between cell components. Due to an improved electrochemical performance, the presented cells are able to work well even at a moderate temperature, thus reducing reactions between cell components and prolonging the stable service period.

Measurement errors. - Potentiometric oxygen sensors measure the $\mathrm{pO}_{2}$ at sensing electrode, $\mathrm{p}_{\mathrm{S}}$, from the Nernst equation of Eq. 1. An error in cell voltage, $\Delta \mathrm{V}$, correspondingly causes an error, $\Delta \mathrm{p}_{\mathrm{S}}$, in $\mathrm{pO}_{2}$ measurement. The relative error is known by:

$$
\frac{\Delta p_{S}}{p_{S}}=\exp \left(\frac{4 F}{R T} \Delta V\right)-1
$$

A slight error of $\pm 1 \mathrm{mV}$ in cell voltage results in a relative error of $\pm 5 \%$ in $\mathrm{pO}_{2}$ measurement at $664^{\circ} \mathrm{C}$. Moderate errors such as $13 \mathrm{mV}$ and $-13 \mathrm{mV}$ in cell voltage give relative errors of $208 \%$ and $-68 \%$ at $263^{\circ} \mathrm{C}$, respectively. A small error in cell voltage measurement can cause relatively large error as the voltage error takes a position at the exponent in Eq. 2. In order to get very precise $\mathrm{pO}_{2}$ measurements calibration with certified gases are necessary. The voltage errors of the cells based on ceramic electrodes were less than $4 \mathrm{mV}$ above $359^{\circ} \mathrm{C}$. The errors in cell voltage of other published IROSes may be known/estimated from References. ${ }^{4-6,11,12,14}$ They are usually greater than $10 \mathrm{mV}$ even at a temperature higher than $600^{\circ} \mathrm{C}$. In some references, the voltage errors are larger than $100 \mathrm{mV}^{11,12}$ It is believed that the quite accurate voltage measurements of our cells based on ceramic electrodes can make them good and stably functioning oxygen sensors.

Unlike an air reference oxygen sensor, the reference $\mathrm{pO}_{2}$ of an IROS is evidently influenced by temperature. The reference $\mathrm{pO}_{2}, \mathrm{p}_{\mathrm{R}}$, of a $\mathrm{Ni} / \mathrm{NiO}$ based IROS is given by:

$$
\ln p_{R}=-\frac{2 \Delta_{r} G^{0}(T)}{R T}
$$

where $\Delta_{r} G^{0}$ is the standard Gibbs free energy of the reaction of $\mathrm{NiO}$ reduction:

$$
\mathrm{NiO}(\mathrm{s}) \rightleftharpoons \mathrm{Ni}(\mathrm{s})+1 / 2 \mathrm{O}_{2}(\mathrm{~g}),
$$

and $\Delta_{r} G^{0}$ is a function of temperature. Therefore the voltage of an IROS is more sensitive to errors on the temperature of the IRE than the voltage of an air reference oxygen sensor is. Particularly care must be taken with respect to temperature measurements so that an IROS is able to determine the $\mathrm{pO}_{2}$ at the sensing electrode with a good accuracy. The temperature difference across the IRE should be as small as possible and the thermocouple detecting cell temperature should be placed as close to the IRE as possible. Calculating the $\mathrm{pO}_{2}$ at sensing electrode by assuming cell temperature equal to the set point temperature of the sensor furnace may reduce the accuracy. ${ }^{14}$ In case the IROS temperature is kept very constant then the accuracy can be obtained by proper calibration of an IROS

A non-hermetic sealing, a not $100 \%$ equilibrated binary mixture of $\mathrm{Ni} / \mathrm{NiO}$, incorrectly measured cell temperature and limitations due to measuring devices, i.e., input resistance of the multimeter is not high enough, can cause errors. An experimental consideration about the accuracy may be worthy noting. At low temperature, the resistance of an IROS may increase to such an extent that the resistance of the voltmeter reading the cell voltage starts to affect the measured cell voltage. For example, at $263^{\circ} \mathrm{C}$ in air, the impedance of cell 2 (IRE/ScYSZ/CSE) is $830 \mathrm{k} \Omega$ at $0.1 \mathrm{~Hz}$. If the input resistance 
of a voltmeter is not large enough, the measured cell voltage will be lowered when the cell is connected to the voltmeter. The input resistance of Keithley 2700, which was used to measure cell voltage in this study, is higher than $10 \mathrm{G} \Omega$. Thus, the cell voltage was not influenced to any significant extent in the tests shown in Figure 4. The impregnation of SDC20 is effective to decrease cell impedance. The ASRs at $315^{\circ} \mathrm{C}$ in air were $33 \mathrm{k} \Omega \cdot \mathrm{cm}^{2}, 17 \mathrm{k} \Omega \cdot \mathrm{cm}^{2}, 27 \mathrm{k} \Omega \cdot \mathrm{cm}^{2}$ and $13 \mathrm{k} \Omega \cdot \mathrm{cm}^{2}$ at $0.1 \mathrm{~Hz}$ for cells $2-5$, respectively. Cell 2 had no SDC20 impregnation and its ASR was relatively high. Cell 3 and cell 5 had SDC20 impregnated into the CSE and their ASRs were noticeably smaller. SDC20 seems effective to lower the cell impedance when it is impregnated into the CSE.

The cells with IREs impregnated by SDC20 showed voltages higher than the theoretical in the temperature range of $260-360^{\circ} \mathrm{C}$. Errors on IRE temperature measurement may possibly account for that. More experiments need to be carried out to study the phenomena. $\mathrm{NiO}$ nonstoichiometry might cause an error in the calculated theoretical voltage depending on how the Gibbs free energy values were obtained. The nonstoichiometry of $\mathrm{NiO}$ is due to nickel vacancies $\left(\mathrm{Ni}_{1-\mathrm{x}} \mathrm{O}\right)$, and the concentration of $\mathrm{Ni}$ vacancies increase with $\mathrm{pO}_{2}$ and temperature. ${ }^{44,45} \mathrm{~A}$ calculation based on reference ${ }^{45}$ shows that $\mathrm{x}$ is around $10^{-5}$ and $10^{-9}$ at $664^{\circ} \mathrm{C}$ and $260^{\circ} \mathrm{C}$ with a $\mathrm{pO}_{2}$ of $1 \mathrm{~atm}$, respectively. As the $\mathrm{NiO}$ nonstoichiometry is expected to be even further decreased under reducing conditions, this is most probably not contributing to the large errors at low temperature seen in Figure 4 . The deviation from the theoretical voltage at low temperature depends seemingly on the details of the oxygen electrode (the SE), and it is believed that the reason for the low temperature error should be found here. It is suggested that at low temperature, the electrode reaction $\mathrm{O}_{2}+4 \mathrm{e}^{-} \leftrightarrows 2 \mathrm{O}^{2-}$ is not reaching equilibrium, and the cell is not at equilibrium but at a steady state. ${ }^{46}$ The quasi-equilibrium $\mathrm{O}_{2}+2 \mathrm{e}^{-} \leftrightarrows \mathrm{O}_{2}{ }^{2-}$, i.e. formation of the peroxide ion, might be the dominant reaction with a much lower equilibrium voltage, similar to the low open circuit voltage observed in low temperature fuels cells like the polymer electrolyte membrane fuel cell (PEMFC). ${ }^{46,47}$

Cell performance.- The cell responds to $\mathrm{pO}_{2}$ variations rapidly as shown in Figure 5. The volume of the test setup is ca. $142 \mathrm{~cm}^{3}$ and the gas flow rate is ca. $5 \mathrm{slph}$ at $663^{\circ} \mathrm{C}$ during $\mathrm{pO}_{2}$ cycling. So the time for purging the setup is ca. 30 seconds that is comparable with the observed response times. The response time had been found to strongly depend on the volume of the experimental setup. A cell with an identical structure as that shown in Figure 5 was tested in the bigger alumina setup and the response time became much longer, more than $2 \mathrm{hrs}$ for a $\mathrm{pO}_{2}$ change from 0.2 to $0.024 \mathrm{~atm}$ at $663^{\circ} \mathrm{C}$. For the identical $\mathrm{pO}_{2}$ change the response time was shorter than 20 seconds in the smaller quartz setup, as shown by Figure 5 . Therefore the response time should be further reduced provided that the volume of the test setup is further reduced or the gas flow rate is further increased. The cell voltage variation in the course of $\mathrm{pO}_{2}$ cycling shows an evident asymmetric behavior. The response is apparently more rapid in changing from low to high $\mathrm{pO}_{2}$ than in the reverse direction. A similar asymmetric response behavior has previously been reported by Anderson et al. ${ }^{22}$ and Fouletier et al. ${ }^{48}$ and was attributed to the logarithmic dependence of cell voltage upon the $\mathrm{pO}_{2}$ at the sensing electrode. ${ }^{22}$ Since the response time shows an evident dependence on temperature kinetic factors such as electrode processes that usually are very temperature dependent may play a substantial role.

The stability comparison and recoverability tests shown in Figure 6 reveal that the IRE depletion is an important factor accounting for the cell voltage decrease. Though a cell voltage decrease may be attributed to various factors, i.e., electrode degradation and poisoning, IRE depletion is one of the most direct factors. Since the equilibrium $\mathrm{pO}_{2}$ of $\mathrm{Ni} / \mathrm{NiO}$ is very small, i.e., $6 \times 10^{-18}$ bar at $664^{\circ} \mathrm{C}$, the depletion of an IRE, in most of cases, is due to Ni depletion instead of NiO depletion. The IRE depletion caused by a non-hermetic sealing is rather common in most of cases. ${ }^{5,11,12,14}$ In this situation, the cell voltage will be stable only in a short term, i.e., a few hours since the gas leak rate is generally fast and the oxidation of $\mathrm{Ni}$ is rapid at high temperature. In our cells, the total amount of $\mathrm{NiO}$ in the IRE before the reduction of $\mathrm{NiO}$ is ca. $2 \mathrm{mg}$, equivalent to ca. $3 \times 10^{-5} \mathrm{~mol}$. Such a small amount of $\mathrm{Ni}$, even if the $\mathrm{NiO}$ is reduced entirely, will be exhausted in a short time once the sealing layer is not hermetic. Thus a non-hermetic sealing may not be the reason accounting for the cell voltage decrease of the test shown in Figure 6. More importantly, the stability test shown in Figure 7 proceeded for more than $5100 \mathrm{hrs}$, which might be used to exclude the possibility of a nonhermetic sealing. It is reasonable to believe that in this study the IRE depletion is caused by oxygen permeation through the electrolyte. A term, "depletion period", is defined here meaning the time that it takes for one of the IRE components, $\mathrm{Ni}$ for most of cases, to be exhausted. The Ni load of an IRE and the factors which affect the oxygen permeation rate determine the depletion period. The permeation rate of oxygen through an electrolyte is characterized by the leak current density, which is determined by electrolyte thickness, electrolyte properties (for example, electron, hole and ion conductivities), $\mathrm{pO}_{2}$ at the sensing electrode and operation temperature. The leak current density can be calculated based on other works ${ }^{49-53}$ and predicts a depletion period of $>10^{4} \mathrm{hrs}$ for the cell shown in Figure 6. The cell voltage is still stable after a service of $5100 \mathrm{hrs}$, within the prediction. The stability test proves that the electronic leak of an electrolyte can be controlled by cell design to such an extent that the cell in service does not need frequent maintenance.

The amount of reduced $\mathrm{NiO}$ depends on cell structures and reduction conditions. The IRE of the cells shown in Figure 6 were reduced at $-1.1 \mathrm{~V}$ for 18 minutes and 755 minutes, respectively, which corresponded to the degrees of reduced $\mathrm{NiO}$ of $11 \%$ and $67 \%$, respectively. The IRE of the cell shown in Figure 7 was reduced for 50 minutes at $-1.0 \mathrm{~V}$, which corresponded to a degree of reduced $\mathrm{NiO}$ of $43 \%$. A depleted IRE can be recovered by the electrochemical method as shown in Figure 6. The recoverability of the IRE originates in the electrode structure. The Ni recovery needs a joint participation of oxide ion, nickel oxide and electrons. If there is no oxide ion passage within the IRE, the whole IRE cannot be recovered except the parts closely confined to the interface of IRE/electrolyte. The IRE of the cells in this study uses a composite electrode structure and the ionic passage is realized by a network of $8 \mathrm{YSZ}$ and/or SDC20, which makes the whole IRE recoverable.

\section{Conclusions}

Durable internal reference oxygen sensors, which use the equilibrium $\mathrm{pO}_{2}$ of the binary mixture of $\mathrm{Ni} / \mathrm{NiO}$ as the reference, are demonstrated. The cells may have suitable composite ceramics or $\mathrm{Pt}$ as the sensing electrode, but the composite ceramics are proven advantageous over Pt with respects to the error in cell voltage at temperatures below $450^{\circ} \mathrm{C}$, cell resistance and working temperature range. The presented cells were fabricated by a flexible and potentially low cost method. The cell performance was elaborately evaluated in terms of accuracy, stability, response time, tolerance to thermal and $\mathrm{pO}_{2}$ cycling and the recoverability, which are the key features for a commercial product. More than 200 cells have been fabricated and more than 30 cells have been tested. Both cell fabrication and performance are highly reproducible. Thus a well performing and reproducible internal reference oxygen sensor that can be applied in practice has been developed.

\section{Acknowledgment}

The authors thank Dr. Karsten Agersted Nielsen for his help in preparation the sealing glass, Dr. Martin Søgaard for providing experimental facilities to test the long term stability. We acknowledge Dr. Eugen Stamate for his help in magnetron sputtering, Dr. Johan Hjelm for his help in ink preparation and Dr. Ming Chen for the help in using Factsage 5.5. Charlotte Maul and Kristian Nim Sørensen fabricated the 8YSZ and ScYSZ tapes. Ebtisam Abdellahi processed the samples for SEM observation. Lene Knudsen and Ulla Forsberg guided the screen printing. We are grateful for the 
valuable discussions with Dr. Søren Koch, Dr. Yi Lin Liu and Ms. Weiwei Zhang. This work was supported financially by The Program Commission on Sustainable Energy and Environment, The Danish Council for Strategic Research, via the Strategic Electrochemistry Research Center (SERC) (www.serc.dk), contract no. 2104-06-0011.

\section{References}

1. N. Yamazoe, Sens. Actuators, B, 108, 2 (2005).

2. R. Ramamoorthy, P. K. Dutta, and S. A. Akbar, J. Mater. Sci., 38, 4271 (2003).

3. W. C. Maskell and B. C. H. Steele, J. Appl. Electrochem., 16, 475 (1986)

4. D. M. Haaland, Anal. Chem., 49, 1813 (1977).

5. A. G. Mortimer and G. P. Reed, Sens. Actuators, B, 24-25, 328 (1995)

6. F. J. G. Monreal and G. Vitter, J. Phys. E: Sci. Instrum., 16, 361 (1983).

7. N. Rajabbeigi, B. Elyassi, A. Khodadadi, S. S. Mohajerzadeh, and M. Sahimi, Sens. Actuators, B, 100, 139 (2004)

8. N. Rajabbeigi, B. Elyassi, A. A. Khodadadi, S. Mohajerzadeh, Y. Mortazavi, and M. Sahimi, Sens. Actuators, B, 108, 341 (2005)

9. R. Hetrick and W. C. Vassell, J. Electrochem. Soc., 128, 2529 (1981)

10. T. M. Gür and R. A. Huggins, Oxygen sensor, US Patent 5,827,415 (1998).

11. A. K. M. S. Chowdhury, S. A. Akbar, S. Kapileshwar, and J. R. Schorr, J. Electrochem. Soc., 148, G91 (2001).

12. E. van Setten, T. M. Gür, D. H. A. Blank, J. C. Bravman, and M. R. Beasley, Rev. Sci. Instrum., 73, 156 (2002).

13. H. Kaneko, T. Okamura, and H. Taimatsu, Sens. Actuators, B, 93, 205 (2003).

14. J. V. Spirig, R. Ramamoorthy, S. A. Akbar, J. L. Routbort, D. Singh, and P. K. Dutta, Sens. Actuators, B, 124, 192 (2007).

15. W. C. Maskell, H. Kaneko, and B. C. H. Steele, J. Appl. Electrochem., 17, 489 (1987).

16. H. Kaneko, W. C. Maskell, and B. C. H. Steele, Solid State Ionics, 22, 161 (1987).

17. W. C Maskell, Solid State Ionics, 134, 43 (2000)

18. H. Kaneko, T. Okamura, H. Taimatsu, Y. Matsuki, and H. Nishida, Sens. Actuators, $B, \mathbf{1 0 8}, 331$ (2005)

19. S. Zhuiykov, Meas. Sci. Technol., 17, 1570 (2006).

20. E. L. Brosha, R. Mukundan, D. R. Brown, F. H. Garzon, J. H. Visser, M. Zanini, Z. Zhou, and E. M. Logothetis, Sens. Actuators, B, 69, 171 (2000).

21. L. Heyne and D. Engelsen, J. Electrochem. Soc., 124, 727 (1977).

22. J. E. Anderson and Y. B. Graves, J. Appl. Electrochem., 12, 335 (1982).

23. N. Yamazoe and Y. Teraoka, Catal. Today, 8, 175 (1990).
24. A. Trovarelli, Catalysis by ceria and related materials, Imperial College Press, London (2002).

25. M. A. Keane, J. Mater. Sci., 38, 4661 (2003).

26. E. J. Baran, Catal. Today, 8, 133 (1990).

27. T. Nakamura, M. Misono, and Y. Yoneda, J. Catal., 83, 151 (1983).

28. F. H. Garzon, R. Mukundan, Roger Lujan, and E. L. Brosha, Solid State Ionics, 175, 487 (2004).

29. E. L. Brosha, R. Mukundan, D. R. Brown, F. H. Garzon, and J. H. Visser, Solid State Ionics, 148, 61 (2002)

30. F. H. Garzon, R. Mukundan, and E. L. Brosha, Solid State Ionics, 136-137, 633 (2000).

31. S. M. Haile, Acta. Mater, 51, 5981 (2003).

32. S. P. Jiang, J. Mater. Sci., 43, 6799 (2008).

33. C. Sun, R. Hui, and J. Roller, J. Solid State Electrochem., 14, 1125 (2010)

34. A. Hauch, S. D. Ebbesen, S. H. Jensen, and M. Mogensen, J. Electrochem. Soc., 155, B1184 (2008).

35. J. E. O'Brien, C. M. Stoots, J. S. Herring, and J. Hartvigsen, J. Fuel Cell Sci. Tech., 3, 213 (2006).

36. V. V. Kharton, F. M. B. Marques, and A. Atkinson, Solid State Ionics, 174, 135 (2004).

37. S. P. Jiang, Mater. Sci. Eng., A, 418, 199 (2006).

38. S. P. Jiang and S. H. Chan, J. Mater. Sci., 39, 4405 (2004).

39. F. Tietz, A. Mai, and D. Stöver, Solid State Ionics, 179, 1509 (2008).

40. S. P. Jiang, J. Solid State Electrochem., 11, 93 (2007).

41. C. W. Bale, E. Bélisle, P. Chartrand, S. A. Decterov, G. Eriksson, K. Hack, I.-H. Jung, Y.-B. Kang, J. Melançon, A. D. Pelton, C. Robelin, and S. Petersen, Calphad, 33, 295 (2009).

42. K. J. Vetter, Electrochemical kinetics: theoretical aspects, Academic Press, New York (1967).

43. H. Schmalzried, Chemical kinetics of solids, Wiley-VCH, Weinheim (1995)

44. W. C. Tripp and N. M. Tallan, J. Am. Ceram. Soc., 53, 531 (1970).

45. S. P. Mitoff, J. Chem. Phys., 35, 882 (1961).

46. J. P. Hoare, J. Electrochem. Soc., 109, 858 (1962).

47. J. Zhang, Y. Tang, C. Song, J. Zhang, and H. Wang, J. Power Sources, 163, 532 (2006).

48. J. Fouletier, H. Seinera, and M. Kleitz, J. Appl. Electrochem., 4, 305 (1974).

49. J. H. Park and R. N. Blumenthal, J. Electrochem. Soc., 136, 2867 (1989).

50. H. Näfe, J. Electrochem. Soc., 144, 3922 (1997).

51. N. S. Choudhury and J. W. Patterson, J. Electrochem. Soc., 117, 1384 (1970).

52. M. Mogensen and T. Jacobsen, ECS Trans., 25, 1315 (2009).

53. T. Jacobsen and M. Mogensen, ECS Trans., 13, 259 (2008). 